\title{
HEAVENLY TEARS - EARTHLY LOSS: DIFFERENT WAYS OF COPING WITH LIFE LOSS IN TEARS IN HEAVEN, CIRCUS, AND SINCE I LOST YOU
}

\author{
Akun \\ akun@binus.edu \\ English Department, Faculty of Humanities, Binus \\ University
}

\begin{abstract}
This is a qualitative study of three pop songs rooted from the same tragic event of Eric Clapton's son Conor who fell from the 53rd floor of his spouse's New York apartment in March 1991. Two songs are from Clapton himself i.e. Tears in Heaven and Circus and one song from his friend Phil Collins entitled Since I Lost You. The goal of this study is to elaborate the attitude of the author through the study of formal aspects of the song such as rhyme, rhythm, tone and picth and also the metaphorical expressions in their wording. This is a library research of the three songs using a comparative technique of elaboration. The study concludes that Phil Collins as a friend who is not directly involved in the tragedy shows his sympathy through a negative and hopeless way of seeing the tragedy. $\mathrm{He}$ focuses more on the tragedy directly rather than the impact, psychologial process and lessons learned afterward. Eric Clapton, on the other hand, as the one who directly suffers the impact of the tragedy sees the tragic event from a more positive angle. He tries to somehow show his grief but does not want to be drifted away in this sorrow. He focuses more on the process after the tragedy-by remembering the sweet moment before the tragedy (in Circus) and imagine the same sweet thing after the tragedy (in Tears in Heaven) by setting an emotional spin around the good memory and nice after life state of the child with sweet hopes and strengthening consolation.
\end{abstract}

Key words: Comparative study, pop songs, attitude, Eric Clapton, Phil Collins 


\begin{abstract}
Abstrak: Ini adalah kajian kualitatif terhadap tiga lagu pop yang berakar dari latar peristiwa tragis yang sama yakni tragedi anak lakilaki Erik Clapton yang bernama Conor yang terjatuh dari lantai 53 apartemen istrinya di New York pada bulan Maret 1991. Dua lagu diciptakan oleh Clapton sendiri yaitu Tears in Heaven dan Circus dan satu lagu lagi dari sahabatnya Phil Collins yang berjudul Since I Lost You. Tujuan dari penelitian ini adalah untuk mengelaborasi sikap sang pengarang melalui kajian terhadap aspek formal lagu seperti rima, ritme, nada sikap dan intonasi serta ekspresi metaforis dalam kata-katanya. Ini adalah kajian pustaka dari tiga lagu tersebut dengan menerapkan teknik elaborasi komparatif. Kajian ini menyimpulkan bahwa Phil Collins sebagai seorang sahabat yang tidak secara langsung terlibat dalam tragedi ini memperlihatkan simpatinya melalui sudut pandang yang negatif dan tanpa harapan dalam menyikapi peristiwa tragis itu. Ia lebih banyak memusatkan perhatiannya langsung pada tragedinya daripada pada dampak dari tragedi itu, proses psikologis yang terjadi dan pelajaran berharga sesudahnya. Sebaliknya, Eric Clapton, sebagai orang yang secara langsung menderita akibat tragedi tersebut justru memandang peristiwa itu dari sudut pandang yang lebih positif. Ia berusaha untuk memperlihatkan duka citanya yang mendalam, namun tidak ingin terhanyut dalam penderitaannya. La lebih memusatkan perhatiannya pada proses sesudah tragedi itu-dengan mengenang saat-saat indah sebelum peristiwa itu (dalam Circus) dan membayangkan momen indah yang sama sesudah tragedi itu (dalam Tears in Heaven) dengan cara mengangkat gejolak emosi di seputar kenangan indah dan baik dari kondisi kehidupan sang anak setelah kehidupan dunia ini dengan harapan-harapan indah dan penghiburan yang menguatkan.
\end{abstract}

Kata kunci: Kajian komparatif, lagu pop, sikap, Eric Clapton, Phil Collins

\title{
INTRODUCTION
}

Song, just like any other literary or art expressions, is a strong medium to communicate something internal to the external world. Song lyric is normally poetic, having so much in common with poetry characteristics such as"acute perceptions, vivid impressions, compressed language, the musically rhythmic use of language, a heightened sense of attentiveness, and an overall intensification coupled with intensity of detail. Poetry is singing thought" (Drury, 2006, p. 216). Through the lines, a song writer pours both consciously and unconsciously necessary emotions, feelings, experiences, 
hopes and other life intricacies, including attitudes in getting over a great loss of someone dear. The expressions can be put across by the one directly involved as a tragedy or someone close as sympathy. But, the tone and can be shockingly different or even inversely anticipated as the following discussion on Eric Clapton and Phil Collins' songs reveals. This can be easily traced from the tone of the song. Just like common responses to a tragic situation, a person may have his or her expressed attitude toward the tragedy, and this is literarily called the tone in literature. It is the attitude of the author toward the subject or theme of his or her creation. In poetry, specifically tone is,

The emotional spin a poet puts on his words; the edge or attitude in the voice of the poem. When we talk to someone, we can hear his tone of voice-how he says something. Sometimes we can even see it (tongue in cheek, for example). In a poem, tone is the coloration of the words, their shading, their warmth or coolness-as in painting. It is also how they sound, their pitch (high or low), harmony (sweet or shrill), and volume (loud or soft)-as in music. (Drury, 2006, p. 322)

There are three songs written in connection to the death of Eric Clapton's son Conor: Tears in Heaven, Circus, and Since I Lost You. The first two songs were written by Clapton himself in collaboration with Will Jennings and Mick Jones while the last song was written by Phil Collins, Mike Rutherford, and Tony Banks. The three songs will be compared as to give better understanding of the tragic reality in the light of understanding that "comparing and contrasting are also natural ways to describe our responses to poetry" (Madden, 2002, p. 31). Damono has even emphasized that comparing is actually done in any research, but in comparative literature, this is the main step or method (Damono, 2009, p. 1). Further, this is also due to the fact that in addition to the previous explanationsone way of comprehending literary works as stated by Mathew Arnold which is still relevant in this context of discussion is to see the relation of one piece of work to others. Arnold plainly put it as follows: "Everywhere there is connection, everywhere there illustration. No single event, no single literature is adequately comprehended except in relation to other events, to other literatures" cited in (Bassnett, 1993, p. 1). It is clear therefore that merely studying one event in one piece of literary work without associating it to other contexts or perceptions is never satisfactory. It does not mean that the singled way of comprehending a literary work is not worth doing or not advantageous; it is just not enough to understand fully the possibilities of responses on the intricate life as the source of all literary expressions. This 
study does not somehow claim to be more accurate, but just to provide those possibilities of different reactions toward a single event so that the event can be better comprehended. This constitutes the basic idea of comparing the different responses through the three songs, to see the diverse responses away from the oneness and to see the oneness beyond the diversity, as Francois Jost has emphasized as follows,

Often, however, great writers and critics have recogniozed that diversity means wealth and that variety is the spice of intellectual life. It is necessary, they have concluded, to study several national literatures in order to become aware of the spendid multiformity of European and even universal letters, and, at the same time, to see their oneness and unity beyond all appearances. The discipline that today is called comparative literature is based on this reflection. (Jost, 1974, p. 9)

Beyond the one and same source of tragedy, Clapton and Collins have responded quite differently toward this very tragedy. But again, this is the wealth of life when diversity is accepted as richness in comprehending one single event. Further, Claudio Guillen as quoted by Juliati, "sugests three focuses of comparison: the authors and the process of writing, the socialhistorical background of the writings, and the discernible problems in the works" (Juliati, 2006, p. 84). It is obvious that there are three possible focuses in a comparative literary study i.e. the author's creative writing process, the context of the work and the issues addressed in the work. The first and the second will be then the focus of this study.

It is mostly undeniable that one can channel any repressed traumatic past event into a certain medium of expression, and Clapton as a singer and song writer did it by pouring his grief, solace, and ideas into a song. The following website explains about the background of the song, in addition to information on who Clapton was working with in creating the work:

Eric Clapton wrote this about his 4-year-old son Conor, who died when he fell out of a 53rd floor window in the apartment where his mother was staying in New York City... Clapton wrote this with Will Jennings, who has written many famous songs from movies, including "Up Where We Belong" from An Officer and A Gentleman and "My Heart Will Go On" from Titanic. Jennings wrote the lyrics to many of Steve Winwood's hits and has also written with B.B. King, Roy Orbison, The Crusaders, Peter Wolf and many others. (Wiser, 2006) 
In case of Tears in Heaven, Clapton had Will Jennings do it - admiring and believing Jennings can best interpret his yearning - though the basic ideas all came from him. The tragedy happened in March 1991 and Clapton was adversely affected by the tragedy, and then consciously showed his intention to put his feelings, emotions and expectations into the song entitled Tears in Heaven. He said, "I want to write a song about my boy". Will Jennings saw this as something so personal and he completely could sense the sensitivity of the situation. The context for the creative process of writing the song and its background can clearly be traced in the following testimony from Jennings:

"Eric had the first verse of the song written, which, to me, is all the song, but he wanted me to write the rest of the verse lines and the release ('Time can bring you down, time can bend your knees...'), even though I told him that it was so personal he should write everything himself. He told me that he had admired the work I did with Steve Winwood and finally there was nothing else but do to as he requested, despite the sensitivity of the subject. This is a song so personal and so sad that it is unique in my experience of writing songs." (Wiser, 2006)

Further, Circus has similar background. Clapton expressed himself as a way to cope with the hard time-he even called it therapy-by writing about the nice day he spent with his son Conor just one day before the accident. The day was so meaningful as Clapton learned thegrace to be a real father despite the fact that he had been ignorant and reluctant as told by Clapton's ex-spouse Lory Del Santo (Clapton, 2007) about his son's existence when he was alive for years. Clapton confessed it in 1998 BBC interview,

"The last night I spent with Conor, we went to the circus. We went to see one of those huge things that they do in America where they have three rings going on at the same time. You've got clowns and tigers and everything. They don't do anything in half measures. They just pile it all in. Plus, they're trying to sell you things at the same time. I mean it was an amazing thing. After the show, we were driving back to New York and all he could remember, all he could talk about was this clown. He'd seen a clown with a knife, which I didn't see at all. Some clown was running around brandishing a knife, which was something quite frightening but he liked it - I mean it excited him. And so that is in the lyrics. But, and I suppose what I was doing, I was 
remembering, I mean paying tribute to this night with him and also seeing him as being the circus of my life. You know - that particular part of my life has now left town.” (Eric, 1998)

The vivid description of what happened during their visit to the circus has later colored the lyric of the song where Clapton has tried to remember, even as tribute to his life, the momental togetherness as he metaphorically called the moment with the son as the "circus" of his life. Phil Collins as a friend of Clapton showed his deep sympathy by writing and singing a song as well: "While on its surface this sounds like just another lament for a love lost, Phil Collins actually wrote it in response to the accidental death of the 4-year-old son of his longtime friend and occasional musical collaborator Eric Clapton" (Songfacts, 1991). The following parts of the article detail the goal, methodology, discussion and conclusion of the study.

The goal of this study is to reveal the attitudes shown by the personas as a way of dealing with hard time, especially in understanding and coping with the death of a beloved child from a father and a friend. This goal is achieved through the study of the song formal aspects i.e. rhyme, rhythm, pitch, tone, and the metaphors used in the songs.

Further, the idea of comparing is also closely connected to metaphor because metaphor is "A comparison that likens two different things by identifying one as the other... unlike simile, methaphor does not use linking words ('like', 'as','such as') to indicate similarity between two otherwise things... Metaphor, however, is also the general term for any comparison, including simile, metaphor, coceit, and analogy" (Drury, 2006, p. 168). Therefore, the study of metaphors in the songs is considered helpful in revealing the attitudes of the personas.

In addition, oxymoron methaphor is another focus. Oxymoron is "an expression that combines opposite, contradictory qualities, seemingly nonsensical but capturing some psychological or emotional extreme ambivalence. Romeo's complaint to Benvolio in Act I, Scene I of Romeo and Juliet is a good example: 'Feather of lead, bright smoke, cold fire, sick health!" (Drury, 2006, p. 206). The repressed emotions toward the loss can thus be traced through this use of oxymoronic methaphor. 


\title{
METHODOLOGY
}

This is a comparative study of three pop songs rooted from the same source of inspiration-the tragic death of a child. The theories on comparative literature will be applied in discussing the points of comparison. Library research is employed in searching for background data around the incident and responses from Eric Clapton, his family, and friends. After the data are gathered, the three songs themselves are analyzed as to elaborate the similarities and differences by detailing the attitude of the author through the study of formal aspects of the song such as rhyme, rhythm, tone and picth that become the aim of this study. Metaphors-including oxymoronic metaphor-used by the song writers will also be analyzed to disclose the attitudes of the personas.

\section{DISCUSSION}

Thecomparative discussion of the songs is divided into three parts: the surface form (rhyme and rhythm) of the songs, the metaphorical expressions used by the song writers,and the attitudes of the personas. The analyses below start with Phil Collins' Since I Lost You and then move on to Clapton's Tears in Heaven and Circus.

Firstly, Collins' Since I Lost You utilizes high pitch (typically matched to Collins' voice) with a rather quick rhythm, giving the impression of mourning and regret. The regular booming of the soft rocking rhythm really gives the nuance of grief and sadness, especially when it is associated with the title Since I Lost You-the loss must have been so heartbreaking. The interlude electric guitar is also roaring to strenthen the idea of mourning the loss. This great loss is emphasized many times through the repetition of the stanza consisting of the following expression (lines 5-7, 14):

\author{
cos my heart is broken in pieces \\ yes my heart is broken in pieces \\ since you've been gone \\ $\cdot$. \\ since I've. lost you (Banks, Collins, \& Rutherfort, 1991)
}

Even the sentence "cos my heart is broken in pieces" is repeated 10 times, stressing the idea of how great is the impact of the loss. 
Then we have a rather loose rhyme (aabc-aab-abbc-aab-abca-abc-aab-aab$\mathrm{aab}$ as can be seen in "shatter-disappear-floor-same; pieces-pieces-gone; granted-say-away-same; pieces-pieces-you; see-know-you-me; tightly-go-same; pieces-pieces-you; pieces-pieces-gone; pieces-pieces-gone") and in a loose stanzaic form ( 9 stanzas, consisting of 3 four-line stanzas and 6 three-line stanzas), signifying the rather instable emotional state in facing the painful reality, though still within control. The song gives a somber and soul screamingtone with high pitches in almost all words at the end of the lines such as on "shatter, disappear, like dust, same, heart, pieces, gone, granted, say, away, lost" indicating brokenheartedness, sudden shock and regret of losing someone.

The metaphors used at the same time give clear depiction of the loss. The metaphoric expression of "a castle in the sand the water takes away" (line 10) shows how sudden is the tragedy happens without prior warning. Castle of course means something or someone so precious, but the sudden coming of the water takes everything away. This instant loss is strengthened by the use of other metaphors previously written at the beginning of the song: "morning dreams" (line 2) and "dust in your hand" (line 3). The morning dreams just disappear in an instant. Presumably the dreams are beautiful dreams which suddently vanish before reaching the end. The "dust in your hand" howeverstresses how fast is the disappearance and just like the soft tiny grains of dust, we can hardly notice that it can suddenly fly away or fall to the floor.

The above discussed outer tone and metaphor also signify the lamenting, regretful and hopeless attitude of the persona. This attitude of regret is openly stated in the fifth stanza (lines 15-18):

ooh now you'll never see

ooh now you'll never know

all the things I planned for you

things for you and me (Banks, Collins, \& Rutherfort, 1991)

The above lines not only picture regret but also lamentation. Still, the regretful tone is stressed and repeated through questioning "how can life ever be the same" (line s $4,11,21$ ) for three times, significant enough to put forward the idea of feeling so sorry for the loss. The whole idea of shocking loss and lamentation can be best represented by the first line that "in a moment your whole world can shatter" (line 1). Therefore, overall, Collins shows his deep sympathy through an attitude of regretting the sudden loss by placing himself in Clapton's difficult position, showing how deep is the 
impact and without any trace of hope for the bright side of the incident. What about Clapton himself? The following part will elaborate his reaction to the same tragedy in his own way.

Eric Clapton's Tears in Heaven shows a different outer tone, mellow and slow, but very regular and in order, especially the rhyme (abab-abab-ababaaab-abcb-aaab-abab-abab as seen in "name-heaven-same-heaven; strong-onbelong-heaven; hand-heaven-stand-heaven; way-day-stay-heaven; down-kneesheart-please; door-sure-more-heaven; name-heaven-same-heaven; strong-onbelong-heaven"). This can be interpreted as stability of emotion while dealing with the hard time. The rhythm or beat of the song is also slow and orderly, with low picthed voice. The tune sounds flat and pitiful. The dominating slow and soft guitar strengthens this image. It is quite clear that the persona has reached a stage of accepting the reality and tries his best to positively think of the tragedy as a lesson in life. He also has used the word "heaven"many times (10 times) to indicate the positive attitude and hope toward the loss. Instead of lamenting that life can ever be the same (in Collins), Clapton hopefully expects that the gone child will feel the same when they meet in heaven. The strong repeated word "heaven" seems to cover all the sadness and give solace to the empty soul. This way the persona realizes his weakness during his ignorant life with the kid and especially after his leaving, but still he tries to see the kid and heaven as the source of strength, hoping that he can help him stand by holding his hand while he is looking for strength night and day. This state is a stage where the persona has realized that time (read life experience) can bring him down, bend his knees and break his heart, but he believes that the child is happy and peaceful in his new heavenly life: "Beyond the door there's peace I'm sure, and I know there'll be no more tears in heaven" (lines 21-24). Besides, the persona consoles and convinces himself that after learning from his own weaknesses through the tragedy he must be stronger and continue his life: "I must be strong and carry on" (lines 29-30). So, there is no sense of regret and negative attitudes traced in this song.

The metaphoric expression used is all related to heaven. The word "door" in the song refers to the door of heaven. And the phrase "Tears in Heaven", -which is actually oxymoron metaphor (we will not assume sadness tears in heaven because heaven is a place of peace and joy) reflects the persona'shealed sadness which again ends in his belief that there will be no more tears in heaven, eventhough for the time being there is still a distance between the persona (father) and the child. 
From the above discussion, we can clearly see the attitude depicted in this song: facing the hard time with realization of the need to become stronger, hoping to meet in another life with better condition, and focusing on the "after tragedy" (pay attention to the use of present conditional and future reference) with the strength got. This is different from Collins' song which is so much focused on the tragedy itself, the regret, present realization that life can never be the same.

The last song, Circus, formally has a very regular rhyme pattern (abcbabcb-ababc-abcb-abcb-abab-aa as shown in "fire-bright-gave-delight; clownknife-hear-life; sad-round-sad-round-town; pure-fine-you-line; you-night-youright; town-town") with low pitch and tune, similar to Tears in Heaven, indicating the positive and stable state of emotion, seeing things from the bright side. This song is on the surface telling a story of the persona and the child's visiting a circus just like Clapton has confessed in the previous part of this writing. But then beyond the surface, the circus man (clown) turns to be an image of a little man with pure heart. In this context, the clown is a metaphor of two sides: the sadness and the strength. The sadness is shown when the entertaining clownis depicted as leaving the town, and froma child's perspective it is sad because the amusement comes to an end. But, further, this can mean that the sadness is experienced by both the father and the son (Clapton and Conor) because their getting warm relationship is finally ended. Clapton himself indicates this in the song through an expression of deep impression or perhaps scar in life i.e. "What you see and what you will hear will last you for the rest of your life" (lines 7-8). While on the bright side, this clown represents a wise and loving man (supposedly a father) who is ready to ride the child to explore the life funs, even to hold and guide him through the darkest night. The man promises and learns to be gentle and smiling and there he will, through the smile, will always remember the son, and everything will be fine, even the most trivial thing in his life and his relationship with the child. Therefore, it is obvious that the father gets pure solace in this confession and acceptance.

The metaphoric "circus" in this song can both signify happiness and sadness as well-thus oxomoric-when Clapton describes it as joyful (note the words: "eyes on fire, smile so bright, toys, fill heart with delight" in lines 1-4). But then at the same time, suddenly he depicts the situation as "so sad, no easy way round, cause the circus left town" (lines 9-13). This is similar to the "tears in heaven", an expression with double meanings. 
However, the tone or attitude of the author is mostly positive and hopeful. Despite the reality that the circus has left town-that the joy of their togetherness has ended-Clapton set his positive emotional spin by giving himself a psychological consolation that everything will be just allright as seen in lines 18-21,

Hold my hand and I'll walk with you

Through the darkest night.

And when I smile I'll be thinking of you

And every little thing will be all right. (Clapton \& Jones, Circus, 1998)

This is the tone of the last two songs, an author's attitude that may be labeled as oxomoric attitude, set-as Drury puts it-through the coloration of the words, their shading, their warmth or coolness, that has finally colored both of Clapton's songs. The two last songs have depicted the ambivalence of tones: sad, sorrowful yet strong, hopeful and positive just as the words "Tears in Heaven" or "Circus" may ambivalently signify. This is quite different from the first song "Since I Lost You" which decisively stresses the desolate and sorrowful attitude toward the tragedy.

\section{CONCLUSION}

Life tragedy can mean different things for different people. This all depends on how the individuals see the tragedy. There is no question that tragedy always brings sadness and sorrow, but that is not the end of everything. However, other people can see it from a different angle, resulting in completely different perception and attitude.

This study has proven that through the study of three different songs rooted from the same tragic event, the perception and attitude depicted in the song can be shockingly different. Through the study of the song external forms (i.e. rhyme, rhythm, tone, or pitch), the metaphoric words and the attitude or tone of the song writers, it is concluded that Phil Collins as a friend who is not directly involved in the tragedy shows his sympathy through a negative and hopeless way of seeing the tragedy. He focuses more on the tragedy directly by stressing how sorrowful the tragic experience is rather than the impact, psychologial process, and lessons learned afterward. Eric Clapton, on the other hand, as the one who directly suffers the impact of the tragedy sees the tragic event from a more positive attitude. He tries to 
somehow show his grief but does not want to be drifted away in this sorrow. He focuses more on the process after the tragedy-by remembering the sweet moment before the tragedy (in Circus) and imagine the same sweet thing after the tragedy (in Tears in Heaven) by setting an emotional spin around the good memory and nice after life state of the child with sweet hopes and strengthening consolation.

\section{REFERENCES}

Banks, T., Collins, P., \& Rutherfort, M. (1991). Since I Lost You. (P. Collins, Performer)

Bassnett, S. (1993). Comparative literature: A critical introduction. Oxford: Blackwell Publishers.

Clapton, E. (2007, November 20). Eric-Clapton.co.uk. Retrieved February 11, 2013, from http://www.eric-clapton.co.uk/interviewsandarticles/loryin terview.htm

Clapton, E., \& Jones, M. (1998). Circus. (E. Clapton, Performer)

Damono, S. D. (2009). Sastra Bandingan: Pengantar Ringkas. Ciputat: Editum.

Drury, J. (2006). The Poetry Dictionary. Ohio: Writer's Digest Books.

Eric, W. (1998, March). Eric Clapton's Songs: The Backstories. Retrieved February 11, 2013, from Where's Eric: http://www.whereseric.com /the-vault/song-information/eric-claptons-songs-backstories

Jost, F. (1974). Introduction to comparative literature. New York: Pegasus.

Juliati. (2006). Common people in Carl Sandburg's poems and Wiji Thukul's: A comparative study. Humanitas:Journal of language and Literature, pp. 84-93.

Madden, F. (2002). Exploring Poetry: Writing and Thinking About Poetry. New York: Longman.

Songfacts. (1991). Since I Lost You by Genesis. Retrieved February 12, 2013, from Songfacts: http://www.songfacts.com/detail.php?id=6329 
Wiser, C. (2006, May 7). Song Facts - Will Jennings. Retrieved February 27, 2012, from Song Facts: http://www.songfacts.com/blog/interviews/ will_jennings

\section{APPENDICES:}

\section{Since I Lost You}

(Tony Banks/Phil Collins/Mike Rutherford, 1991)

It seems in a moment, your whole world can shatter (a) 1 like morning dreams they just disappear a) like dust in your hand falling to the floor $\quad$ (b) how can life ever be the same

cos my heart is broken in pieces

(a) 5

yes my heart is broken in pieces

(a)

since you've been gone

It's all too easy to take so much for granted

but it's so hard to find the words to say

like a castle in the sand the water takes away

(b) 10

how can life ever be the same

(c)

cos my heart is broken in pieces

(a)

yes my heart is broken in pieces

(a)

since I've lost you

ooh now you'll never see

(a) 15

ooh now you'll never know

(b)

all the things I planned for you

(c)

things for you and me

(a)

I held your hand so tightly

(a)

that I couldn't let it go

(b) 20

Now how can life ever be the same

(c)

cos my heart is broken in pieces

(a)

yes my heart is broken in pieces

(a)

since I've lost you

(b)

cos my heart is broken in pieces

(a) 25

yes my heart is broken in pieces

(a)

since you've been gone

(b) 
14 Celt, Volume 14, Number 1, July 2014, pp 1-15

cos my heart is broken in pieces

(a)

yes my heart is broken in pieces

(a)

since you've been gone

(b) $\quad 30$

\section{Tears in Heaven}

(Eric Clapton/Will Jennings, 1992)

Would you know my name

(a) 1

If I saw you in heaven?

(b)

Would it be the same

(a)

If I saw you in heaven?

(b)

I must be strong

(a) 5

And carry on,

(b)

'Cause I know I don't belong

(a)

Here in heaven.

Would you hold my hand

(a)

If I saw you in heaven?

(b) 10

Would you help me stand

(a)

If I saw you in heaven?

(b)

I'll find my way

(a)

Through night and day,

'Cause I know I just can't stay

(a) 15

Here in heaven.

(b)

Time can bring you down,

Time can bend your knees.

Time can break your heart,

Have you begging please, begging please.

(b) 20

Beyond the door,

(a)

There's peace I'm sure,

And I know there'll be no more

Tears in heaven.

Would you know my name

(a) 25

If I saw you in heaven?

(b)

Would it be the same

(a)

If I saw you in heaven? 
I must be strong

(a)

And carry on,

(b) 30

'Cause I know I don't belong

(a)

Here in heaven.

(b)

REPEAT FIRST VERSE

\section{CIRCUS}

(Eric Clapton \& Mick Jones, 1998)

Little man with his eyes on fire

(a) 1

And his smile so bright.

(b)

In his hands are the toys you gave

(c)

To fill his heart with delight.

(b)

And in the ring stands a circus clown

(a) 5

Holding up a knife.

(b)

What you see and what you will hear

Will last you for the rest of your life.

And it's sad, so sad,

There ain't no easy way round.

And it's sad, so sad,

(b) 10

All you friends gather round

'Cause the circus left town.

(c)

Little man with his heart so pure

(a)

And his love so fine.

(b) 15

Stick with me and I'll ride with you

(c)

Till the end of the line.

(b)

Hold my hand and I'll walk with you

(a)

Through the darkest night.

(b)

And when I smile I'll be thinking of you

(a) 20

And every little thing will be all right.

(b)

CHORUS:

The circus left town, left town.

(a)

The circus left town, left town. 